\title{
Does silvoagropecuary landscape fragmentation affect the genetic diversity of the sigmodontine rodent Oligoryzomys longicaudatus?
}

\begin{abstract}
Daniela Lazo-Cancino $^{1}{ }^{\text {, }}$, Selim S Musleh ${ }^{2}$, Cristian E Hernandez ${ }^{1}$, Eduardo Palma ${ }^{3}$, Enrique Rodriguez-
\end{abstract} Serrano ${ }^{\text {Corresp. } 1}$

${ }^{1}$ Departamento de Zoologia, Universidad de Concepción, Concepción, Biobío, Chile

2 Departamento de Oceanografía, Universidad de Concepción, Concepción, Biobío, Chile

3 Departamento de Ecología, Pontificia Universidad Católica de Chile, Santiago, Chile

Corresponding Author: Enrique Rodriguez-Serrano

Email address: enrodriguez@udec.cl

Background. Fragmentation of native forests is a highly visible result of human land-use throughout the World. In this study, we evaluated the effects of landscape fragmentation and matrix features on the genetic diversity and structure of Oligoryzomys longicaudatus, the natural reservoir of Hantavirus in southern South America. We focused our work in the Valdivian Rainforest where human activities have produced strong change of natural habitats, with an important number of human cases of Hantavirus. Methods. We sampled specimens of $O$. longicaudatus from five native forest patches surrounded by silvoagropecuary matrix from Panguipulli, Los Rios Region, Chile. Using the hypervariable domain I (mtDNA), we characterized the genetic diversity and evaluated the effect of fragmentation and landscape matrix on the genetic structure of $O$. longicaudatus. For the latter, we used three approaches: i) Isolation by Distance (IBD) as null model, ii) Least-cost Path (LCP) where genetic distances between patch pairs increase with cost-weighted distances, and iii) Isolation by Resistance (IBR) where the resistance distance is the average number of steps that is needed to commute between the patches during a random walk. Results. We found low values of nucleotide diversity $(\pi)$ for the five patches surveyed, ranging from 0.012 to 0.015 , revealing that the 73 sampled specimens of this study belong to two populations but with low values of genetic distance $\left(\mathrm{\gamma}_{\mathrm{ST}}\right)$ ranging from 0.022 to 0.099 . Likewise, we found that there are no significant associations between genetic distance and geographic distance for IBD and IBR. However, we found for the LCP approach, a significant positive relationship $(r=0.737, p=0.05)$, with shortest least-cost paths traced through native forest and arborescent shrublands Discussion. In this work, we found that, at this reduced geographical scale, Oligoryzomys longicaudatus shows genetic signs of fragmentation. In addition, we found that connectivity between full growth native forest remnants is mediated by the presence of dense shrublands and native forest 
corridors. In this sense, our results are important because they show how native forest patches and associated routes act as source of vector species in silvoagropecuary landscape, increasing the infection risk on human population. This study is the first approach to understand the epidemiological spatial context of silvoagropecuary risk of Hantavirus emergence. Further studies are needed to elucidate the effects of landscape fragmentation in order to generate new predictive models based on vector intrinsic attributes and landscape features. 


\section{Does silvoagropecuary landscape fragmentation affect the 2 genetic diversity of the sigmodontine rodent Oligoryzomys 3 longicaudatus?}

5 Daniela Lazo-Cancino ${ }^{1,2}$, Selim S. Musleh ${ }^{3}$, Cristián E. Hernández ${ }^{4}$, R. Eduardo Palma ${ }^{5}$ \&

6 Enrique Rodríguez-Serrano ${ }^{1 *}$

$7 \quad{ }^{1}$ Laboratorio de Mastozoología, Departamento de Zoología, Facultad de Ciencias Naturales y

8 Oceanográficas, Universidad de Concepción, Concepción, Chile

92 Programa de Magister en Ciencias, mención Zoología, Facultad de Ciencias Naturales y

10 Oceanográficas, Universidad de Concepción, Concepción, Chile.

$11{ }^{3}$ Departamento de Oceanografía, Universidad de Concepción, Concepción, Chile

$12{ }^{4}$ Laboratorio de Ecología Evolutiva y Filoinformática, Departamento de Zoología, Facultad de

13 Ciencias Naturales y Oceanográficas, Universidad de Concepción, Concepción, Chile.

$14{ }^{5}$ Laboratorio de Biología Evolutiva, Departamento de Ecología, Facultad de Ciencias

15 Biológicas, Pontificia Universidad Católica de Chile, Santiago, Chile.

*Corresponding Author:

Dr. Enrique Rodríguez-Serrano ${ }^{1}$

Barrio Universitario s/n, Concepción, Biobío, 4070386, Chile

Email address: enrodriguez@udec.cl 


\section{Abstract}

Background. Fragmentation of native forests is a highly visible result of human land-use throughout the World. In this study, we evaluated the effects of landscape fragmentation and matrix features on the genetic diversity and structure of Oligoryzomys longicaudatus, the natural reservoir of Hantavirus in southern South America. We focused our work in the Valdivian Rainforest where human activities have produced strong change of natural habitats, with an important number of human cases of Hantavirus.

Methods. We sampled specimens of $O$. longicaudatus from five native forest patches surrounded by silvoagropecuary matrix from Panguipulli, Los Rios Region, Chile. Using the hypervariable domain I (mtDNA), we characterized the genetic diversity and evaluated the effect of fragmentation and landscape matrix on the genetic structure of $O$. longicaudatus. For the latter, we used three approaches: i) Isolation by Distance (IBD) as null model, ii) Least-cost Path (LCP) where genetic distances between patch pairs increase with cost-weighted distances, and iii) Isolation by Resistance (IBR) where the resistance distance is the average number of steps that is needed to commute between the patches during a random walk.

Results. We found low values of nucleotide diversity $(\pi)$ for the five patches surveyed, ranging from 0.012 to 0.015 , revealing that the 73 sampled specimens of this study belong to two populations but with low values of genetic distance $\left(\gamma_{\mathrm{ST}}\right)$ ranging from 0.022 to 0.099 . Likewise, we found that there are no significant associations between genetic distance and geographic distance for IBD and IBR. However, we found for the LCP approach, a significant positive relationship ( $r=0.737, p=0.05$ ), with shortest least-cost paths traced through native forest and arborescent shrublands

Discussion. In this work, we found that, at this reduced geographical scale, Oligoryzomys longicaudatus shows genetic signs of fragmentation. In addition, we found that connectivity between full growth native forest remnants is mediated by the presence of dense shrublands and native forest corridors. In this sense, our results are important because they show how native forest patches and associated routes act as source of vector species in silvoagropecuary landscape, increasing the infection risk on human population. This study is the first approach to understand the epidemiological spatial context of silvoagropecuary risk of Hantavirus emergence. Further studies are needed to elucidate the effects of landscape fragmentation in order to generate new predictive models based on vector intrinsic attributes and landscape features. 


\section{Introduction}

Habitat fragmentation is widely recognized as a major threat to global biodiversity (Brooks et al., 2002; Secretariat of the Convention on Biological Diversity, 2005). In this process, a large wild habitat changes into a number of small isolated patches as consequence of human activities (Wilcove, McLellan \& Dobson, 1986; Fahrig, 1997, 2003). Those changes imply gradual or accelerated reduction of original habitat's area (Young, Boyle \& Brown, 1996; Lande, 1998; Fahrig, 2003). The main intraspecific consequences of habitat fragmentation are discontinuities on the distribution of resources and species' optimal environmental conditions, leading to a decrease in connectivity among fragmented populations (Vos and Stumpel 1995; Lees and Peres 2008). Thus, fragmentation isolates population, reduces gene flow, the genetic diversity and the effective population size, favoring genetic processes such as drift and inbreeding (Allendorf \& Luikart, 2007; Johansson, Primmer \& Merilä, 2007; Taylor et al., 2011). In addition, habitat fragmentation can affect the fitness reducing adaptive responses to local selective environments and may cause local extinction (Bolger et al., 1997; Frankham, 2005; Johansson, Primmer \& Merilä, 2007; Willi et al., 2007; Bijlsma \& Loeschcke, 2012).

Recently, it has been proposed that the structure of the landscape matrix is the main modulator of the consequences of fragmentation on biodiversity (Gascon et al., 1999; Debinski, 2006). Accordingly, if the surrounding matrix has structural similarity with the original habitat remnants, the inter-patch migration is granted avoiding important reduction of patch species richness (Gascon et al., 1999; Ricketts, 2001; Prugh et al., 2008; Franklin \& Lindenmayer, 2009; Driscoll et al., 2013). Although this proposal has strong support on different fragmented systems, the genetic consequence of the fragmentation in vertebrates has a strong bias to Tropical Forest species (Radespiel \& Bruford, 2014). Further, the intraspecific consequence of the matrix permeability has been studied mainly on European vertebrate or insect species (e.g. McRae, 2006; Arens et al. 2007; Emaresi et al. 2011; van Strien et al. 2012).

The patch's connectivity is often measured through fixation indexes and isolation by distance (Manel et al., 2003). However, Arens et al. (2007) use an explicit calculation of matrix permeability variables, for the study of connectivity among Moor frog patches from Netherlands, highlighting the importance of incorporating the landscape complexity on the evaluation of genetic connectivity. This imply that a simple isolation by distance model is insufficient to explain the genetic diversity in a system of patches surrounded by a matrix of several land-uses. Thus, numerous approaches have been developed in recent years, accounting for the matrix complexity with different theoretical foundations. According to van Strien et al. (2012), these approaches can be categorized into two groups: those using transects and those using matrix features to establish landscape cost/resistance surfaces. For the latter, there are two popular approaches, least-cost distance model and the circuit theory model (e.g., Walker \& Craighead, 1997; Adriaensen et al., 2003; McRae, 2006). The least-cost distance models minimize the travel distance among habitat patches and the cost traversed, offering the shortest cumulative costweighted distance (optimal route) between an origin patch to a destination patch. On the other 
97 hand, McRae (2006) proposed a model based on circuit theory that "predicts a positive

98

99

100

101

102

103

104

105

106

107

108

109

110

111

112

113

114

115

116

117

118

119

120

121

122

123

124

125

126

127

128

129

130

131

132

133

134

135 relationship between genetic differentiation and the resistance distance, a distance metric that exploits precise relationships between random walk times and effective resistances in electronic networks". Thus, these new approaches allow to understand the effecst on the genetic diversity of the patch-matrix dynamics.

During the last 30 years, the Mediterranean and the Temperate Chilean landscapes have been strongly modified by silvoagropecuary activities (agricultural, lumbering and industrial forestry activities), where remnants of native forests are restricted to zones with difficult access (Bustamante \& Grez, 1995; Aguayo et al., 2009). Then, these patches of natural habitats constitute a highly fragmented environment, where patches are surrounded by different productive crops, exotic forestry species (mainly Eucalyptus globulus and Pinus radiata), and secondary regrowth native forest.

A frequent species in the Mediterranean and Temperate Forests of Chile is the long - tailed pygmy rice rat ("Colilargo"), Oligoryzomys longicaudatus (Bennett, 1832). This sigmodontine rodent has a broad distribution in Chile and Argentina. In Chile it occurs from $27^{\circ} \mathrm{S}$ to $54^{\circ} \mathrm{S}$ (Belmar-Lucero et al., 2009), whereas in Argentina ranges from $36^{\circ} \mathrm{S}$ to $51^{\circ} \mathrm{S}$ on the eastern slope of the Andes mountains (Carbajo \& Pardiñas, 2007). Oligoryzomys longicaudatus shows a high vagility and a large home range $320-4800 \mathrm{~m}^{2}$, with seasonal fluctuations (Murúa et al. 1986). The species is mainly granivorous, inhabiting microhabitats with dense foliage, which could be related to its saltorial mode of locomotion and as a mechanism to avoid predators (Murúa, Gonzalez \& Jofre, 1980; Murúa \& González, 1982). Molecular studies based on cytochrome $b$ mitochondrial DNA (mtDNA) sequences have shown a marked genetic homogeneity along the species geographic distribution (Palma et al., 2005). However, studies based on hypervariable domain I (HVI) of the mtDNA recovered a geographical structure of populations in agreement with the ecoregions and the three recognized subspecies along the species range (Palma et al. 2012a), and a temporal genetic variability at local scale (Boricbargetto et al., 2012). In addition, $O$. longicaudatus has been the focus of numerous epidemiological studies, given that the species is the major reservoir of the Andes strain of Hantavirus that causes a cardiopulmonary syndrome to human populations with a mortality rate of about 35\% (Toro et al. 1998; Martínez-Valdebenito 2014). Thus, to evaluate the effects of changing landscapes on the migration and connectivity of $O$. longicaudatus populations, and the potential effect on infection rates, especially on peri-urban areas, constitute highly relevant issues to the ecology, the genetics and the epidemiology of this species (Torres-pérez et al., 2004). Therefore, in this study we evaluated the effects of landscape fragmentation and matrix structure on the genetic diversity and genetic structure of $O$. longicaudatus. We focused our work on a portion of the southern Temperate Forest (the Valdivian Rain Forest) where human activities have produced a strong impact on natural habitats, and where an important number of human cases of Hantavirus have been reported in Chile (http://epi.minsal.cl). 
136

137

138

139

140

141

142

143

144

145

146

147

148

149

150

151

152

153

154

155

156

157

158

159

160

161

162

163

164

165

166

167

168

169

170

171

172

\section{Materials \& Methods}

\section{Study site and specimens analyzed}

The Valdivian Temperate Forest - southern Chile and nearby Argentina - is one of the 25 biodiversity hotspots of the world threatened by anthropogenic activities (Olson, 1998; Myers et al., 2000). This biome/ecoregion has been considered a biogeographic island that harbors a quite diverse assemblage of mammals where native species are mostly restricted to national parks and rural areas with fragmented landscapes (Echeverría et al., 2007). For this study, we took samples of $O$. longicaudatus from 5 different patches of dense native, full growth, temperate forests in a total area of $3.5 \mathrm{~km}^{2}$. The specimens were trapped with standard Sherman traps $(8 \times 9 \times 23 \mathrm{~cm}$, H. B. Sherman Traps, Inc., Tallahassee, FL, USA). The field trapping procedure was conducted through a regular grid sampling design, setting 450 traps night for three nights, and we used oat and vanilla as bait.

The study was conducted during the autumn and winter of 2007 in the locality of Curirruca, Panguipulli province, Los Rios region southern Chile (3948'30" S, 73¹4'30" W; Fig. 1). The captures were conducted under the Chilean Government authorization: Resolución Exenta $\mathrm{N}^{\circ}$ 7325 (December 30, 2005; from Servicio Agrícola y Ganadero, Ministerio de Agricultura, Gobierno de Chile). We selected this temporal window because it did not match with the reproductive period of the species and the mobility among patches should be reduced (Murúa et al. 1986). The patches sampled were surrounded by a matrix - the rest of landscape after exclusion of habitat patches - characterized by recent adult and/or harvested plantations, grasslands and shrublands areas, agricultural fields, and/or adjacent to forest roads (Table S1). The appropriate landscape soil uses for the sampling year were obtained from the Chilean Government National Environmental Information System - SINIA (http://ide.mma.gob.cl/).

The present study was conducted using blood samples and liver tissue from 73 specimens of $O$. longicaudatus, collected in this area (Table S2). All specimens were handled following the standard bioethical and biosafety protocols proposed by the American Society of Mammalogists (ASM; Sikes et al. 2011), and the Center for Diseases Control and Prevention (CDC; Mills et al. 1995), respectively.

\section{Laboratory methods}

DNA was extracted using the Wizard ${ }^{\circledR}$ Genomic DNA Purification Kit (PROMEGA ${ }^{\circledR}$, Madison, Wisconsin). Through the polymerase chain reaction (PCR) we amplified $\sim 1100 \mathrm{bp}$ from mtDNA from which we used 527 bp corresponding to the hypervariable subunit I (HVI) and part of the conservative domain of the Control Region. The mammalian mtDNA hypervariable regions are included within the extended terminal associated sequences (ETAS) and conserved sequence block (CSB; Vigilant et al. 1991; Sbisà, Elisabetta et al. 1997; Pesole et al. 1999). The evolution of D-loop region in mammals is characterized by a strong rate heterogeneity among sites, tandem repeated elements and high frequency of insertion/deletion 
173 events (Saccone, Pesole \& Sbisà, 1991; Wakeley, 1993; Sbisà et al., 1997; Pesole et al., 1999).

174 The ETAS and CSB domains evolve fast enough to be used for population genetics studies 175 (Wakeley, 1993; Sbisà et al., 1997; Pesole et al., 1999; Rosel et al., 1999; Kerth, Mayer \&

176 König, 2000; Matson et al., 2000).

177 We used primers DLO-L (5' CGG AGG CCA ACC AGT AGA 3') and DLO-H (5' TAA GGC 178 CAG GAC CAA ACC 3'; Belmar-Lucero et al. 2009; Palma et al. 2012) according to the 179 following thermal profile: an initial denaturation of $5 \mathrm{~min}$. at $94^{\circ} \mathrm{C}$, followed by 25 or 30 cycles 180 of denaturation for $30 \mathrm{~s}$ at $94^{\circ} \mathrm{C}$, annealing for $30 \mathrm{~s}$ at $57^{\circ} \mathrm{C}$ and extension for $1 \mathrm{~min} .30 \mathrm{~s}$ at 72 $181{ }^{\circ} \mathrm{C}$, and a final extension of $5 \mathrm{~min}$. at $72^{\circ} \mathrm{C}$. The PCR products were sent to Macrogen 182 (http://dna.macrogen.com/) for purification and sequencing (Applied Biosystems 3730XL 183 sequencer). Sequences were edited with BioEdit v 7.2.5 (Hall, 1999) and aligned using ClustalW 184 (Thompson, Higgins \& Gibson, 1994).

185

186

187

188

189

190

191

192

193

194

195

196

197

198

199

200

201

202

203

204

205

206

207

208

209

\section{Data analyses}

\section{Genetic diversity}

To describe the genetic diversity in all the patches studied we used the DnaSP Software v 5.10.01 (Librado \& Rozas, 2009) to estimate the number of haplotypes (Nh), segregating sites $(\mathrm{S})$, the haplotype diversity (Hd) and the nucleotide diversity $(\pi)$. The same software was used to calculate the Gamma $\operatorname{ST}_{\mathrm{ST}}\left(\gamma_{\mathrm{ST}}\right.$; Nei 1982) a statistical index of genetic differentiation that represents an unbiased estimate of the population subdivision fixation index $\left(\mathrm{F}_{\mathrm{ST}}\right)$ and its use is more appropriate for haplotype data. Statistical significance of genetic differentiation was tested using Hudson's nearest neighbor statistics $\left(\mathrm{S}_{\mathrm{nn}}\right)$ with 1,000 permutations in DnaSP. $\mathrm{S}_{\mathrm{nn}}$ statistics indicates the frequency with which nearest neighbor sequences are found in the same group (Hudson, 2000).

\section{Fragmentation effect}

To evaluate the fragmentation effects on the genetic structure of $O$. longicaudatus we estimated the number of panmictic units in the landscape surveyed using the package GENELAND v 3.2.2 (Guillot, Mortier \& Estoup, 2005) in the R software (R Core Team, 2016). For this, we follow the proposal of Guillot et al. (2012) codding the data in such a way that the various haplotypes of mtDNA are recoded as alleles of a single locus. This package implements a statistical model with Bayesian inference and uses geo-referenced data of the sequenced individuals, inferring and locating genetic discontinuities between populations. The number of clusters was determined by running MCMC (Markov chain Monte Carlo) iterations to estimate $K$ (i.e., the most probable number of populations). The analysis was performed in both non-correlated and correlated model, allowing values of $K$ to vary from 1 to 5, running MCMC with 10,000,000 iterations sampling each 1,000. To choose the best model that fits the data, a $\log 10$ Bayes Factor (BF) with 1,000 bootstrap replicates was performed in Tracer $\mathrm{v} 1.5$ (http://tree.bio.ed.ac.uk/software/tracer/). The model that better fitted our data was the correlated 
210 allele frequency model, which assumes that rare alleles in a certain populations are also rare in 211 other populations (Guillot, Mortier \& Estoup, 2005).

\section{Landscape matrix effect}

213 For the identification of landscape matrix effects on the genetic structure of $O$. longicaudatus we 214 followed three approaches. First, we performed isolation by distance test (IBD) as a null model,

215 because this model contains no information about landscape features, where dispersal occurs in 216 homogenous geographic spaces (Nowakowski et al., 2015). IBD was performed using vegan 217 package 2.4-1 package (Oksanen et al., 2016) implemented in R (R Core Team, 2016). IBD was 218 tested using a mantel test with 119 permutations between a matrix of genetic distances $\left(\gamma_{\mathrm{ST}}\right)$ and 219 a matrix of geographic distances between the 5 patches. Second, we used Least-Cost Path (LCP) 220 analysis. In LCP, genetic distances between patch pairs increase with cost-weighted distances, 221 taking into account the friction effects of the landscape on the individual movement process

222 (Adriaensen et al., 2003; Epps et al., 2007). Third, we used isolation by resistance (IBR)

223 analysis, where dispersal occurs in heterogeneous landscapes and the resistance distance is the

224 average number of steps that is needed to commute between the patches during a random walk

225 that is calculated using the circuit theory (McRae, 2006).

226 To estimate the distances under LCP and IBR models we used the package gdistance (van Etten, 227 2017). For this, we first fed the gdistance package with a raster file containing the landscape 228 features of the study area classified in five classes: native forest (all age classes), grassland and shrublands (with/out arborescent elements), farm (agricultural use), plantation forestry (monoculture of exotic species, eg. Pinus radiata) and mix forest (zone with both native and introduced trees). The raster resolution was $0.008 \times 0.0006$ pixels, but for technical feasibility we created a raster layer with larger cells $(0.048 \times 0.0034$ pixels of resolution $)$ using raster package 2.5-8 (Hijmans, 2015, 2016) in R (R Core Team, 2016). Second, we used transition function of gdistance to create a transitions matrix which represents the transition from one cell to another on a grid where each cell is connected to its 8 neightbours. In short, this function calculates the conductance values from the values of each pair of cells to be connected (van Etten, 2017). However, there are two distance distortions that need to be corrected; diagonal neighbors are more remote from each other than orthogonal neighbours, and on a longitude-latitude grids, West-East connections are longer at the equator and shorter towards the poles. To solve these distortions, we used geoCorrection function. For the transition matrix used in LCP, this function divides each value from the matrix by distance between cell centers (van Etten, 2017). On the other hand, for the transition matrix used in IBR, the function weights the probability of reaching an adjacent cell in a random walk by making it proportional to the surface covered by the cell, multiplying the North-South transition values with the cosine of the average latitude of the two cell centers that are being connected (van Etten, 2017). To calculate least-cost distances between patches, we used costDistance function that computes the cost units as the reciprocal of the values in the transition matrix using the Djkstra's algorithm (Dijkstra, 1959). To calculate the resistance distances between patches, we used commuteDistance function, this function uses the 
249 algorithm implemented by Fouss et al. (2007) to calculate the expected random walk commute

250 time between patches, resulting in the average number of steps needed to commute between the

251 locations (van Etten, 2017).

252 To perform the correlation between genetic distances $\left(\gamma_{\mathrm{ST}}\right)$ with both, LCP and IBR distances, we

253 used vegan package 2.4-1 package (Oksanen et al., 2016) in R (R Core Team, 2016) performing

254 a mantel test with 119 permutations. This number of permutations is the maximum number

255 allowed to avoid duplication due the size of matrix distance (i.e. $5 \times 5$ ). Finally, we used

256 gdistance 1.1-9 package (van Etten, 2015) to trace the quickest path among pairs of patches for

257 LCP model applying shortestPath function which calculates the shortest path from one patch to

258 another. This allowed us to know if there were specific types of soil use (the surrounding matrix)

259 that the "Colilargo" uses as a corridor. 


\section{Results}

\section{Genetic diversity}

264 We found a total of 43 segregating sites and 36 haplotypes out from 73 sequences (Table 1). All

265 patches showed a high haplotype diversity (Hd), although FR5 showed the lowest value (0.867)

266 whereas FR2 exhibited the highest values (0.987) (Table 1). Regarding nucleotide diversity $(\pi)$,

267 it was low, ranging from 0.012 (FR4) to 0.015 (FR1) (Table 1).

\section{Genetic structure}

269 Results of GENELAND v 3.2 .2 (Fig. 2) for population genetic structure inferred that the most

270 probable number of clusters of individuals was two $(K=2)$. The first cluster grouped sequences

271 from FR3 and FR4 (Fig 2A). The second cluster joined the patches FR1, FR2 and FR5 (Fig 2B).

272 We found high posterior probabilities (0.9) for cluster assignation (Fig. 2).

273 Pairwise $\gamma_{\mathrm{ST}}$ values (Table 2) revealed the occurrence of genetic differentiation recorded for FR3

274 and FR5 $\left(\gamma_{\mathrm{ST}}=0.099, \mathrm{p}=0.046\right)$, and between FR4 and FR5 $\left(\gamma_{\mathrm{ST}}=0.085, \mathrm{p}=0.044\right)$. The

275 remaining patches showed $\gamma_{\mathrm{ST}}$ values ranging from 0.022 to 0.096 (not significantly different

276 from 0).

\section{Landscape matrix effects}

278 We found that $O$. longicaudatus did not exhibit significant isolation-by-distance, $\gamma_{\mathrm{ST}}$ was not 279 correlated with geographic distance $(r=0.694, p=0.075$, Fig. 3A). However, we found for the 280 least cost path approach a significant positive relationship $(r=0.737, p=0.05$, Fig. $3 \mathrm{~B})$. But, the 281 long-tailed pygmy rice rat did not exhibit a significant isolation by resistance relationship for 282 genetic differentiation ( $r=0.740, p=0.058$, Fig. 3C). The shortest paths traced for LCP shows 283 that individuals of $O$. longicaudatus moved with preference through young and all growth native 284 forest, and grassland with arborescent shrublands to connect patch pairs (Fig. 4). 


\section{Discussion}

288 In this work, we found that, at this reduced geographical scale, Oligoryzomys longicaudatus

289

290

291

292

293

294

295

296

297

298

299

300

301

302

303

304

305

306

307

308

309

310

311

312

313

314

315

316

317

318

319

320

321

322

323

324

325 shows genetic signs of fragmentation. Also, we found that genetic distance between patches showed best fitting to a LCP model. In addition, we found that connectivity between full growth native forest remnants is mediated by the presence of dense shrublands and native forest corridors. The latter can be composed by different age and health status native formations (Fig. 1B; Fig. 4). These results complement previous efforts to understand the association between landscape attributes and the genetic diversity of this species. Previous studies have been focused on regional and local scales proposing relationships between haplogroups and ecogeographic regions, as well as latitudinal genetic structure in local context (Belmar-Lucero et al. 2009; Palma et al. 2012a; Ortiz et al. 2017). Specifically, Ortiz et al. (2017), studying a fragmented landscape in the Argentinian Patagonia, found that landscape features such as lakes, rivers, roads and urban settlements constrain the movement of $O$. longicaudatus, acting as barriers reducing gene flow. Our results support the latter findings since, even at this small scale, showing abrupt changes in land use being the species strongly affected by the fragmentation of the primary habitat.

The long - tailed pygmy rice rat has a marked foraging behavior characterized by the search of seeds, a highly localized and temporally variable resource (Murúa, González \& Meserve, 1986). Previous studies on this species suggested high flexibility in habitat use, characterized by an opportunistic behavior and large home range (Murúa and González 1986; Murúa et al. 1986; Spotorno et al. 2000). In addition, studies based in the Valdivian Rainforest (dense full growth forest at Villarrica National Park) strongly suggest that migration is the modulator of the diversity and temporal genetic structure of $O$. longicaudatus (Boric-Bargetto et al., 2012). Thus, the landscape matrix effects on the genetic diversity and genetic structure of this species would be largely buffered by its high vagility features particularly in the Valdivian Rainforest which is its primary habitat (Murúa, González \& Meserve, 1986). However, we found that the LCP model is the best predictor of the genetic distance for the fragments surveyed. This implies that $O$. longicaudatus minimize the tradeoff between distance travelled and the costs traversed. Graphically, our results showed that the shortest paths among patch pairs are across native forest (the species' primary habitat), representing the routes of maximum efficiency for landscape connectivity, while the rest of land uses would act, in some extent, as barriers.

Our results should be viewed with caution, in terms of some possible consequences derived from our interpretations. If the most efficient routes connecting patches are through native forest, this does not mean that individuals of $O$. longicaudatus occurs only in native forest. If dispersing individuals follow these optimal routes, they would increase the probability of survival reaching the optimal destination (another patch). This is because, dispersal through optimal routes and their associated habitats increases increases the likelihood of finding resources and evading predation (Walker \& Craighead, 1997). In fact, Moreira-Arce et al. (2015) found that $O$. longicaudatus is the preferred prey of the culpeo fox (Lycalopex culpaeus) only in monocultures, 
326

327

328

329

330

331

332

333

334

335

336

337

338

339

340

341

342

343

344

345

346

347

348

349

350

351

352

353

354

355

356

357

358

359

360

361

362

363

364

365

increasing its predation risk in silvoagropecuary landscapes. However, dispersing individuals may not choose the optimal route, and travel through other types of soil use less effectively, because of connectivity among patches. For instance, due to its opportunistic behavior and according to previous ecological studies settled in coastal ranges of the Valdivian Rainforest, this species could be found on grassland - shrublands when the seed availability increases on this area but not on the native forest (Murua \& Gonzalez, 1986; Murúa, González \& Meserve, 1986). In tree monocultures, this rodent is less abundant, but not absent, than in native forest and exhibits an omnivorous diet, where mainly consumes seeds (e.g. Pinus radiata seeds) and fruits, and arthropods and mushrooms in less amount (Muñoz-Pedreros, Murua \& Gonzalez, 1990; Moreira-Arce et al., 2015). Another important caveat of this work is the molecular marker used to infer the genetic structure and diversity of the Colilargo. We used a very variable fragment from the mtDNA, then our results reflect the matrilineal genetic diversity and least cost paths. The major consequence of this choice, is that just a quarter of the total effective population size is used in this study, so the results could underestimate the genetic diversity of each patch, but not the routes, since the latter are estimated from the properties of the landscape (van Etten, 2017). Finally, given that our sampling period was during the autumn and winter, our results may reflect connectivity aspects of Colilargo modulated by the features of those seasons.

Interestingly, a previous ecological work on O. longicaudatus, settled in Temperate Forest, shows that a very marked seasonal reproductive period from October to May, which overlaps with the recruitment period from March to April, is followed by population peaks during autumn-winter (Murúa et al., 1986). Therefore, our sampling was carried out post-recruitment, so the results of genetic diversity and structuring are relevant to estimate connectivity in this fragmented system since these patterns are the result of migration processes between patches that have already occurred.

Oligoryzomys longicaudatus is recognized as the major reservoir of the Andes strain of Hantavirus (ANDV) in Southern South America (Medina et al., 2009). This virus causes the Hantavirus Cardiopulmonary Syndrome (HCPS) disease (Martinez-Valdebenito et al. 2014). In Valdivia, Chile, Mansilla (2006) found that $>50 \%$ of HCPS cases were associated to silvoagropecuary landscapes (Holz \& Palma, 2012). In addition, the long - tailed pygmy rice rat is one of the most common species in the rodent assemblages, where it could potentially infect other wild rodent species with the ANDV (horizontal transmission to coexisting species; Palma et al. 2012b), thus increasing the risk to humans (Polop et al., 2010; Andreo et al., 2012; Barrera $\&$ Murúa, 2016). In this sense, our results are important because they show how native forest patches and associated routes act as source of vector species in silvoagropecuary landscape, highly associated to human activities increasing the infection risk on human population. Further studies are required to elucidate the effects of landscape fragmentation at large scales (i.e. ecogeographic), in order to gain a deeper understanding of the underlying causes of HCPS infection risk in the Valdivian Forest. Finally, a general pattern of the consequences of Temperate Forest fragmentation should be based on an important number of species, and future efforts should point out to other endemic species of this ancient landscape of South America. 


\section{Acknowledgments}

367 We thank the Laboratory work of R. A. Cancino and the Acuigen Team (R. Galleguillos, C.B.

368 Canales-Aguirre, V. Herrera and S. Ferrada). In addition, we are deeply grateful to the Chilean

369 Hanta Field Team in Panguipulli (S. Belmar, G. Carrasco, V. Castro, V. Escobar, P. Gutiérrez,

370 and R. Thompson). Finally, we acknowledge all comments and suggestions made by the

371 Academic Editor and three anonymous reviewers. 


\section{References}

Abbott KD., Ksiasek TG., Mills JN. 1999. Long-term hantavirus persistence in rodents populations in central Arizona. Emerging Infectious Diseases 5:102-112. DOI: 10.3201/eid0501.990112.

Adriaensen F., Chardon JP., Blust G De., Swinnen E., Villalba S., Gulinck H., Matthysen E. 2003. The application of "least-cost" modelling as a functional landscape model. Landscape and Urban Planning 64:233-247. DOI: 10.1016/S0169-2046(02)00242-6.

Aguayo M., Pauchard A., Azócar G., Parra O. 2009. Cambio del uso del suelo en el centro sur de Chile a fines del siglo XX. Entendiendo la dinámica espacial y temporal del paisaje. Revista Chilena de Historia Natural 82:361-374. DOI: http://dx.doi.org/10.4067/S0716$078 X 2009000300004$.

Allendorf FW., Luikart G. 2007. Conservation and the genetics of populations. 2007. Malden, MA: Blackwell Publishing Google Scholar.

Andreo V., Provensal C., Levis S., Pini N., Enría D., Polop J. 2012. Summer - autumn distribution and abundance of the hantavirus host, Oligoryzomys longicaudatus, in northwestern Chubut, Argentina. Journal of Mammalogy 93:1559-1568. DOI: 10.1644/11MAMM-A-201.1.

Arens P., van der Sluis T., van't Westende WPC., Vosman B., Vos CC., Smulders MJM. 2007. Genetic population differentiation and connectivity among fragmented Moor frog (Rana arvalis) populations in The Netherlands. Landscape Ecology 22:1489-1500. DOI: 10.1007/s10980-007-9132-4.

Barrera K., Murúa R. 2016. Nuevo desafío en Salud Pública: Presencia de reservorios de Hanta, Oligoryzomys longicaudatus y Rattus spp., en aéreas de borde en praderas del sur de Chile. Sustainability, Agri, Food and Environmental Research 3:33-46. DOI: http://dx.doi.org/10.7770/safer-V3N3-art966.

Belmar-Lucero S., Godoy P., Ferrés M., Vial PA., Palma RE. 2009. Range expansion of Oligoryzomys longicaudatus (Rodentia, Sigmodontinae) in Patagonian Chile, and first record of Hantavirus in the region. Revista Chilena de Historia Natural 82:265-275. DOI: http://dx.doi.org/10.4067/S0716-078X2009000200008.

Bijlsma R., Loeschcke V. 2012. Genetic erosion impedes adaptive responses to stressful environments. Evolutionary Applications 5:117-129. DOI: 10.1111/j.17524571.2011.00214.x.

Bolger DT., Alberts AC., Sauvajot RM., Potenza P., Mccalvin C., Tran D., Mazzoni S., Soul ME. 1997. Response of Rodents to Habitat Fragmentation in Coastal Southern California. Ecological Applications 7:552-563. DOI: 10.1890/10510761(1997)007[0552:RORTHF]2.0.CO;2.

Boric-bargetto D., Rodríguez-serrano E., Hernández CE., Jaksic FM., Palma RE. 2012. Temporal variation in genetic diversity during an outbreak of Oligoryzomys longicaudatus 
410

(Rodentia, Sigmodontinae) in a temperate forest of southern Chile. Biochemical Systematics and Ecology 44:383-389. DOI: 10.1016/j.bse.2012.06.009.

Brooks TM., Mittermeier RA., Mittermeier CG., Fonseca GABDA., Rylands AB., Konstant WR., Flick P., Pilgrim J., Oldfield S., Magin G., Hilton-taylor C. 2002. Habitat Loss and Extinction in the Hotspots of Biodiversity. Conservation Biology 16:909-923. DOI: 10.1046/j.1523-1739.2002.00530.x.

Bustamante R., Grez AA. 1995. Consecuencias ecológicas de la fragmentación de los bosques nativos. Ambiente y Desarrollo 11:58-63.

Carbajo AE., Pardiñas UF. J. 2007. Spatial Distribution Model of a Hantavirus Reservoir , the Long-Tailed Colilargo (Oligoryzomys longicaudatus), in Argentina. Journal of Mammalogy 88:1555-1568. DOI: https://doi.org/10.1644/06-MAMM-A-183R1.1.

Debinski DM. 2006. Forest fragmentation and matrix effects: the matrix does matter. Journal of Biogeography 33:1791-1792. DOI: 10.1111/j.1365-2699.2006.01596.x.

Dijkstra E. 1959. A Note on Two Problems in Connexion with Graphs. Numerische Mathematik 1:269-271. DOI: 10.1007/BF01386390.

Driscoll DA., Banks SC., Barton PS., Lindenmayer DB., Smith AL. 2013. Conceptual domain of the matrix in fragmented landscapes. Trends in Ecology \& Evolution 28:605-613. DOI: 10.1016/j.tree.2013.06.010.

Echeverría C., Newton AC., Lara A., Benayas JMR., Coomes DA. 2007. Impacts of forest fragmentation on species composition and forest structure in the temperate landscape of southern Chile. Global Ecology and Biogeography 16:426-439. DOI: 10.1111/j.14668238.2007.00311.x.

Epps CW., Wehausen JD., Bleich VC., Torres SG., Brashares JS. 2007. Optimizing dispersal and corridor models using landscape. Journal of Applied Ecology 44:714-724. DOI: 10.1111/j.1365-2664.2007.01325.x.

Fahrig L. 1997. Relative Effects of Habitat Loss and Fragmentation on Population Extinction. Journal of Wildlife Management 61:603-610.

Fahrig L. 2003. Effects of Habitat Fragmentation on Biodiversity. Annual Review of Ecology and Systematics 34:487-515. DOI: 10.1146/annurev.ecolsys.34.011802.132419.

Fouss F., Pirotte A., Renders J. M., Saerens M. 2007. Random-Walk Computation of Similarities between Nodes of a Graph with Application to Collaborative Recommendation. IEEE Transactions on Knowledge and Data Engineering 19:355-369.

Frankham R. 2005. Genetics and extinction. Biological Conservation 126:131-140. DOI: 10.1016/j.biocon.2005.05.002.

Franklin JF., Lindenmayer DB. 2009. Importance of matrix habitats in maintaining biological diversity. PNAS 106:349-350. DOI: 10.1073/pnas.0812016105. 
446

447

448

449

450

451

452

453

454

455

456

457

458

459

460

461

462

463

464

465

466

467

468

469

470

471

472

473

474

475

476

477

478

479

480

481

Gascon C., Lovejoy TE., Bierregaard Jr RO., Malcolm JR., Stou PC., Vasconcelos HL., Laurance WF., Zimmerman B., Tocher M., Borges S. 1999. Matrix habitat and species richness in tropical forest remnants. Biological Conservation 91:223-229. DOI: http://dx.doi.org/10.1016/S0006-3207(99)00080-4.

Guillot G., Mortier F., Estoup A. 2005. Geneland: a computer package for landscape genetics. Molecular Ecology Notes 5:712-715. DOI: 10.1111/j.1471-8286.2005.01031.x.

Guillot G., Renaud S., Ledevin R., Michaux J., Claude J. 2012. A unifying model for the analysis of phenotypic, genetic and geographic data. Systematic Biology, 61: 897-911.

Hall TA. 1999. BioEdit: a user-friendly biological sequence alignment editor and analysis program for Windows 95/98/NT. Nucleic Acids Symposium Series 41:95-98.

Hijmans RJ. 2015. raster: Geographic Data Analysis and Modeling. R package. DOI: http://cran.r-project.org/package=raster.

Hijmans RJ. 2016. Introduction to the "raster" package (version 2.5-8).

Holz A., Palma RE. 2012. Floraciones de bambúes en Chile y Argentina: actual floración masiva del coligue, historia natural y riesgos asociados. Revista Bosque Nativo 50:40-46.

Hudson RR. 2000. A New Statistic for Detecting Genetic Differentiation. Genetics 155:20112014.

Johansson M., Primmer CR., Merilä J. 2007. Does habitat fragmentation reduce fitness and adaptability? A case study of the common frog (Rana temporaria). Molecular Ecology 16:2693-2700. DOI: 10.1111/j.1365-294X.2007.03357.x.

Kerth G., Mayer F., König B. 2000. Mitochondrial DNA (mtDNA) reveals that female Bechstein's bats live in closed societies. Molecular Ecology 9:793-800. DOI: 10.1046/j.1365-294x.2000.00934.x.

Lande R. 1998. Anthropogenic, Ecological and Genetic Factors in Extinction and Conservation Anthropogenic factors Ecological factors Environmental fluctuations and catastrophes. Researches on Population Ecology 40:259-269. DOI: 10.1007/BF02763457.

Lees AC., Peres CA. 2008. Conservation Value of Remnant Riparian Forest Corridors of Varying Quality for Amazonian Birds and Mammals. Conservation Biology 22:439-449. DOI: $10.1111 /$ j.1523-1739.2007.00870.x.

Librado P., Rozas J. 2009. DnaSP v5: a software for comprehensive analysis of DNA polymorphism data. Bioinformatics 25:1451-1452. DOI: 10.1093/bioinformatics/btp187.

Manel S., Schwartz MK., Luikart G., Taberlet P. 2003. Landscape genetics: combining landscape ecology and population genetics. Trends in Ecology \& Evolution 18:8-9. DOI: 10.1016/S0169-5347(03)00008-9.

Mansilla R. 2006. Estudio epidemiológico de una serie de casos de infección por hantavirus y su relación con variables temporo-espaciales en la provincia de Valdivia. Tesis de magíster, 
482

483

484

485

486

487

488

489

490

491

492

493

494

495

496

497

498

499

500

501

502

503

504

505

506

507

508

509

510

511

512

513

514

515

516

517

Facultad de Ciencias Veterinarias, Universidad Austral de Chile.

Martinez-valdebenito C., Calvo M., Vial C., Mansilla R., Marco C., Palma RE., Vial PA., Valdivieso F., Mertz G., Ferrés M. 2014. Person-to-Person Household and Nosocomial Transmission of Andes, Southern Chile, 2011. Emerging Infectious Diseases 20:1629-1636. DOI:10.3201/eid2010.140353.

Matson CW., Rodgers BE., Chesser RK., Baker RJ. 2000. Genetic Diversity of Clethrionomys glareolus Populations from highly contaminated sites in the Chornobyl Region, Ukraine. Environmental Toxicology and Chemistry 19:2130-2135. DOI: 10.1002/etc.5620190824.

McRae BH. 2006. Isolation by resistance. Evolution 60:1551-1561. DOI: 10.1111/j.00143820.2006.tb00500.x.

Medina RA., Torres-Perez F., Galeno H., Navarrete M., Vial PA., Palma RE., Ferres M., Cook JA., Hjelle B. 2009. Ecology, genetic diversity, and phylogeographic structure of Andes virus in humans and rodents in Chile. Journal of virology 83:2446-2459. DOI: DOI: 10.1128/JVI.01057-08.

Mills JN., Yates TL., Childs JE., Parmenter RR., Ksiazek TG. 1995. Guidelines for Working with Rodents Potentially Infected with Hantavirus. Journal of Mammalogy 76:716-722. DOI: https://doi.org/10.2307/1382742.

Moreira-Arce D., Vergara PM., Boutin S., Simonetti JA., Briceño C., Acosta-Jamett G. 2015. Native forest replacement by exotic plantations triggers changes in prey selection of mesocarnivores. Biological Conservation 192:258-267. DOI: https://doi.org/10.1016/j.biocon.2015.09.015.

Muñoz-Pedreros A., Murua R., Gonzalez L. 1990. Nicho ecológico de micromamíferos en un agroecosistema forestal de Chile central. Revista Chilena de Historia Natural 63:267-277.

Murua R., Gonzalez LA. 1986. Regulation of numbers in two Neotropical rodent species in southern Chile. Revista Chilena de Historia Natural 59:193-200.

Murúa R., González LA. 1982. Microhabitat Selection in Two Chilean Cricetid Rodents. Oecologia 52:12-15.

Murúa AR., Gonzalez LA., Jofre C. 1980. Experimental Food Preferences of Two Southern Chilean Rodents. Journal of Mammalogy 61:138-140. DOI: 10.2307/1379972.

Murúa R., González LA., Meserve PL. 1986. Population Ecology of Oryzomys longicaudatus Philippii (Rondentia: Cricetidae). Journal of Animal Ecology 55:281-293. DOI: $10.2307 / 4708$.

Myers N., Mittermeier RA., Mittermeier CG., Fonseca GAB., Kent J. 2000. Biodiversity hotspots for conservation priorities. Nature 403:853-858. DOI: 10.1038/35002501.

Nei M. 1982. Evolution of human races at gene level. In: Human Genetics. New York: Alan R. Liss Inc., 167-181. 
518

519

520

521

522

523

524

525

526

527

528

529

530

531

532

533

534

535

536

537

538

539

540

541

542

543

544

545

546

547

548

549

550

551

552

553

554

555

556

Nowakowski AJ., Dewoody JA., Fagan ME., Willoughby JR., Donnelly MA. 2015. Mechanistic insights into landscape genetic structure of two tropical amphibians using field-derived resistance surfaces. Molecular Ecology 24:580-595. DOI: 10.1111/mec.13052.

Oksanen J., Blanchet G., Friendly M., Kindt R., Legendre P., McGlinn D., Minchin PR., O’Hara RB., Simpson GL., Solymos P., Stevens MHH., Szoecs E., Wagner H. 2016. Vegan: Community Ecology Package. R Package version 2.4-1. DOI: http://cran.rproject.org/package $=$ vegan.

Olson DM. 1998. The Global 200: A Representation Approach to Conserving the Earth's Most Biologically Valuable Ecoregions. Issues in Intermational Conservation 12:502-515. DOI: 10.1046/j.1523-1739.1998.012003502.x.

Ortiz N., Polop FJ., Andreo VC., Provensal MC., Polop JJ., Gardenal CN., González-Ittig RE. 2017. Genetic population structure of the long-tailed pygmy rice rat (Rodentia, Cricetidae) at different geographic scales in the Argentinean Patagonia. Journal of Zoology 301:215226. DOI: $10.1111 /$ jzo.12410.

Palma RE., Boric-bargetto D., Torres-Pérez F., Hernández CE., Yates TL. 2012a. Glaciation Effects on the Phylogeographic Structure of Oligoryzomys longicaudatus (Rodentia: Sigmodontinae) in the Southern Andes. PLoS ONE 7:1-12. DOI: 10.1371/journal.pone.0032206.

Palma RE., Polop JJ., Owen RD., Mills JN. 2012b. Ecology of Rodent-Associated Hantaviruses in the Southern Cone of South America: Argentina, Chile, Paraguay, and Uruguay. Journal of Wildlife Diseases 48:267-281.

Palma RE., Rivera-milla E., Salazar-bravo J., Torres-pérez F., Pardiñas UFJ., Marquet PA., Spotorno AE., Meynard AP., Terry L. 2005. Phylogeography of Oligoryzomys longicaudatus (Rodentia: Sigmodontinae) in Temperate South America. Journal of Mammalogy 86:191-200. DOI: https://doi.org/10.1644/15451542(2005)086<0191:POOLRS $>2.0$. CO;2.

Parmenter CA., Yates TL., Parmenter RL., Mills JN., Childs JE., Campbell ML., Dunnum JL., Milner J. 1998. Small mammal survival and trapability in mark-recapture monitoring programs for hantavirus. Journal of Wildlife Diseases 34:1-12. DOI: 10.7589/0090-355834.1.1.

Pesole G., Gissi C., Chirico A De., Saccone C. 1999. Nucleotide Substitution Rate of Mammalian Mitochondrial Genomes. Journal of Molecular Evolution 48:427-434. DOI: 10.1007/PL00006487.

Polop FJ., Provensal C., Pini N., Levis SC., Priotto W., Enría D., Calderon G., Costa F., Polop JJ. 2010. Temporal and Spatial Host Abundance and Prevalence of Andes Hantavirus in Southern Argentina. EcoHeath 7:176-184. DOI: 10.1007/s10393-010-0333-y.

Prugh LR., Hodges KE., Sinclair ARE., Brashares JS. 2008. Effect of habitat area and isolation on fragmented animal populations. PNAS 105:20770-20775. DOI: 10.1073/pnas.0806080105. 
557 R Core Team. 2016. R: A language and environment for statistical computing. $R$ Foundation for 558 Statistical Computing, Vienna, Austria.

559

560

561

562

563

564

565

566

567

568

569

570

571

572

573

574

575

576

577

578

579

580

581

582

583

584

585

586

587

588

589

590

591

592

593

594

Radespiel U., Bruford MW. 2014. Fragmentation genetics of rainforest animals: insights from recent studies. Conservation Genetics 15:245-260. DOI: 10.1007/s10592-013-0550-3.

Ricketts TH. 2001. The Matrix Matters : Effective Isolation in Fragmented Landscapes. The American naturalist 158:87-99. DOI: 10.1086/320863.

Rosel PE., France SC., Wang JY., Kocher TD. 1999. Genetic structure of harbour porpoise Phocoena phocoena populations in the northwest Atlantic based on mitochondrial and nuclear markers. Molecular Ecology 8:41-54. DOI: https://doi.org/10.1046/j.1365294X.1999.00758.x.

Saccone C., Pesole G., Sbisà E. 1991. The Main Regulatory Region of Mammalian Mitochondrial DNA : Structure-Function Model and Evolutionary Pattern. Journal of Molecular Evolution 33:83-91. DOI: 10.1007/BF02100199.

Sbisà E., Tanzariello F., Reyes A., Pesole G., Saccone C. 1997. Mammalian mitochondrial Dloop region structural analysis: identification of new conserved sequences and their functional and evolutionary implications. Gene 205:125-140. DOI: http://dx.doi.org/10.1016/S0378-1119(97)00404-6.

Secretariat of the Convention on Biological Diversity. 2005. Handbook of the Convention on Biological Diversity Including its Cartagena Protocol on Biosafety. Montreal, Canada.

Sikes RS., Gannon WL., Mammalogist TAC and UC of the AS of. 2011. Guidelines of the American Society of Mammalogists for the use of wild mammals in research. Journal of Mammalogy 92:235-253. DOI: 10.1644/10-MAMM-F-355.1.

Taylor AC., Walker FM., Goldingay RL., Ball T., Ree R Van Der. 2011. Degree of Landscape Fragmentation Influences Genetic Isolation among Populations of a Gliding Mammal. PLoS ONE 6:1-9. DOI: 10.1371/journal.pone.0026651.

Thompson JD., Higgins DG., Gibson TJ. 1994. CLUSTAL W : improving the sensitivity of progressive multiple sequence alignment through sequence weighting, position-specific gap penalties and weight matrix choice. Nucleic Acids Research 22:4673-4680. DOI: https://doi.org/10.1093/nar/22.22.4673.

Toro J., Vega JD., Khan AS., Mills JN., Terry W., Yadón Z., Valderrama R., Barbara A., Pavletic C., Cerda R., Zaki S., Wun-ju S., Meyer R., Tapia M., Mansilla C., Baro M., Vergara A., Concha M., Calderon G., Enria D., Ksiazek TG. 1998. An Outbreak of Hantavirus Pulmonary Syndrome, Chile, 1997. Emerging Infectious Diseases 4:687-694. DOI: $10.3201 /$ eid0404.980425.

Torres-pérez F., Navarrete-droguett J., Aldunate R., Yates TL., Mertz GJ., Vial PA., Ferrés M., Marquet PA., Palma RE. 2004. Peridomestic Small Mammals Associated with Confirmed Cases of Human Hantavirus Disease in Southcentral Chile. The American Journal of tropical medicine and hygiene 70:305-309. DOI: 
595

596

597

598

599

600

601

602

603

604

605

606

607

608

609

610

611

612

613

614

615

616

617

618

619

620

621

622

623

624

625

626

627

https://doi.org/10.4269/ajtmh.2004.70.305.

Torres-Pérez F., Palma RE., Hjelle B., Ferrés M., Cook JA. 2010. Infection, Genetics and Evolution Andes virus infections in the rodent reservoir and in humans vary across contrasting landscapes in Chile. Infection, Genetics and Evolution 10:820-825. DOI: 10.1016/j.meegid.2009.07.004.

van Etten J. 2015. gdistance: Distances and Routes on Geographical Grids. R package. DOI: http://cran.r-project.org/package $=$ gdistance.

van Etten J. 2017. R Package gdistance: Distances and Routes on Geographical Grids. Journal of Statistical Software 76. DOI: 10.18637/jss.v076.i13.

van Strien MJ., Keller D., Holderegger R. 2012. A new analytical approach to landscape genetic modelling: least-cost transect analysis and linear mixed models. Molecular Ecology 21:4010-4023. DOI: 10.1111/j.1365-294X.2012.05687.x.

Vigilant L., Stoneking M., Harpending H., Hawkes K., Wilson AC. 1991. African Populations and the Evolution of Human Mitochondrial DNA. Science 253:1503-1507. DOI: $10.1126 /$ science. 1840702 .

Vos CC., Stumpel AHP. 1995. Comparison of habitat-isolation parameters in relation to fragmented distribution patterns in the tree frog (Hyla arborea). Landscape Ecology 11:203-214. DOI: 10.1007/BF02071811.

Wakeley J. 1993. Substitution Rate Variation Among Sites in Hypervariable Region 1 of Human Mitochondrial DNA. Journal of Molecular Evolution 37:613-623. DOI: 10.1007/BF00182747.

Walker R., Craighead L. 1997. Analyzing wildlife movement corridors in Montana using GIS. In: Proceedings of the 1997 ESRI user conference, Redlands, USA.

Wilcove DS., McLellan CH., Dobson AP. 1986. Habitat Fragmentation in the Temperate Zone. In: Soulé M ed. Conservation Biology: the science of scarcity and diversity. Sunderland: Sinauer Associates, Inc., 237-256.

Willi Y., Buskirk JVAN., Schmid B., Fischer M. 2007. Genetic isolation of fragmented populations is exacerbated by drift and selection. Journal of Evolutionary Biology 20:534542. DOI: 10.1111/j.1420-9101.2006.01263.x.

Young A., Boyle T., Brown T. 1996. The population genetic consequences of habitat fragmentation for plants. Tree 11:413-418. DOI: http://dx.doi.org/10.1016/01695347(96)10045-8. 


\section{Table $\mathbf{1}$ (on next page)}

Descriptive statistics of the genetic variation of $O$. longicaudatus

Descriptive statistics of the genetic variation of $O$. longicaudatus sequences for each sampled patch. N: Number of individuals, S: segregating sites, Nh: haplotype number, Hd: haplotype diversity, $\pi$ : nucleotide diversity, SD: standard deviation. 
1 Descriptive statistics of the genetic variation of $O$. longicaudatus sequences for each sampled patch. $N$ :

2 Number of individuals, S: segregating sites, Nh: haplotype number, $\mathrm{Hd}$ : haplotype diversity, $\pi$ :

3 nucleotide diversity, SD: standard deviation.

\begin{tabular}{l|lllll} 
Patches & $N$ & $S$ & $N h$ & $\mathrm{Hd} \pm \mathrm{SD}$ & $\pi \pm \mathrm{SD}$ \\
\hline FR1 & 12 & 22 & 9 & $0.939 \pm 0.058$ & $0.015 \pm 0.002$ \\
FR2 & 18 & 33 & 16 & $0.987 \pm 0.023$ & $0.014 \pm 0.001$ \\
FR3 & 9 & 20 & 8 & $0.972 \pm 0.064$ & $0.013 \pm 0.002$ \\
FR4 & 24 & 28 & 13 & $0.880 \pm 0.056$ & $0.012 \pm 0.002$ \\
FR5 & 10 & 21 & 7 & $0.867 \pm 0.107$ & $0.013 \pm 0.002$ \\
Total & 73 & 43 & 36 & $0.954 \pm 0.012$ & $0.014 \pm 0.001$
\end{tabular}

4 


\section{Table 2 (on next page)}

Pairwise genetic distances between native forest patches

Pairwise genetic distances between patches ( $y s t$ ) (below diagonal) and $\mathrm{S}_{\mathrm{NN}}$ significance Pvalues (above diagonal). Bold numbers represent significant values. 
1 Pairwise genetic distances between patches ( $p s t$ ) (below diagonal) and $\mathrm{S}_{\mathrm{NN}}$ significance P-values (above 2 diagonal). Bold numbers represent significant values.

3

\begin{tabular}{l|lllll}
\multicolumn{2}{c}{ FR1 } & FR2 & FR3 & FR4 & FR5 \\
\hline FR1 & - & 0.835 & 0.735 & 0.588 & 0.31 \\
FR2 & 0.022 & - & 0.586 & 0.351 & 0.379 \\
FR3 & 0.091 & 0.049 & - & 0.346 & 0.046 \\
FR4 & 0.096 & 0.062 & 0.030 & - & 0.044 \\
FR5 & 0.038 & 0.027 & 0.099 & 0.085 & -
\end{tabular}

4 


\section{Figure 1}

GIS representation and satellite image of the study site.

A) Land uses, roads, and native forest patches (fragments "FRX") where individuals of

Oligoryzomys longicaudatus were sampled. B) Google Earth Image of the study site depicting the fragments and the high heterogeneity of the land uses. 

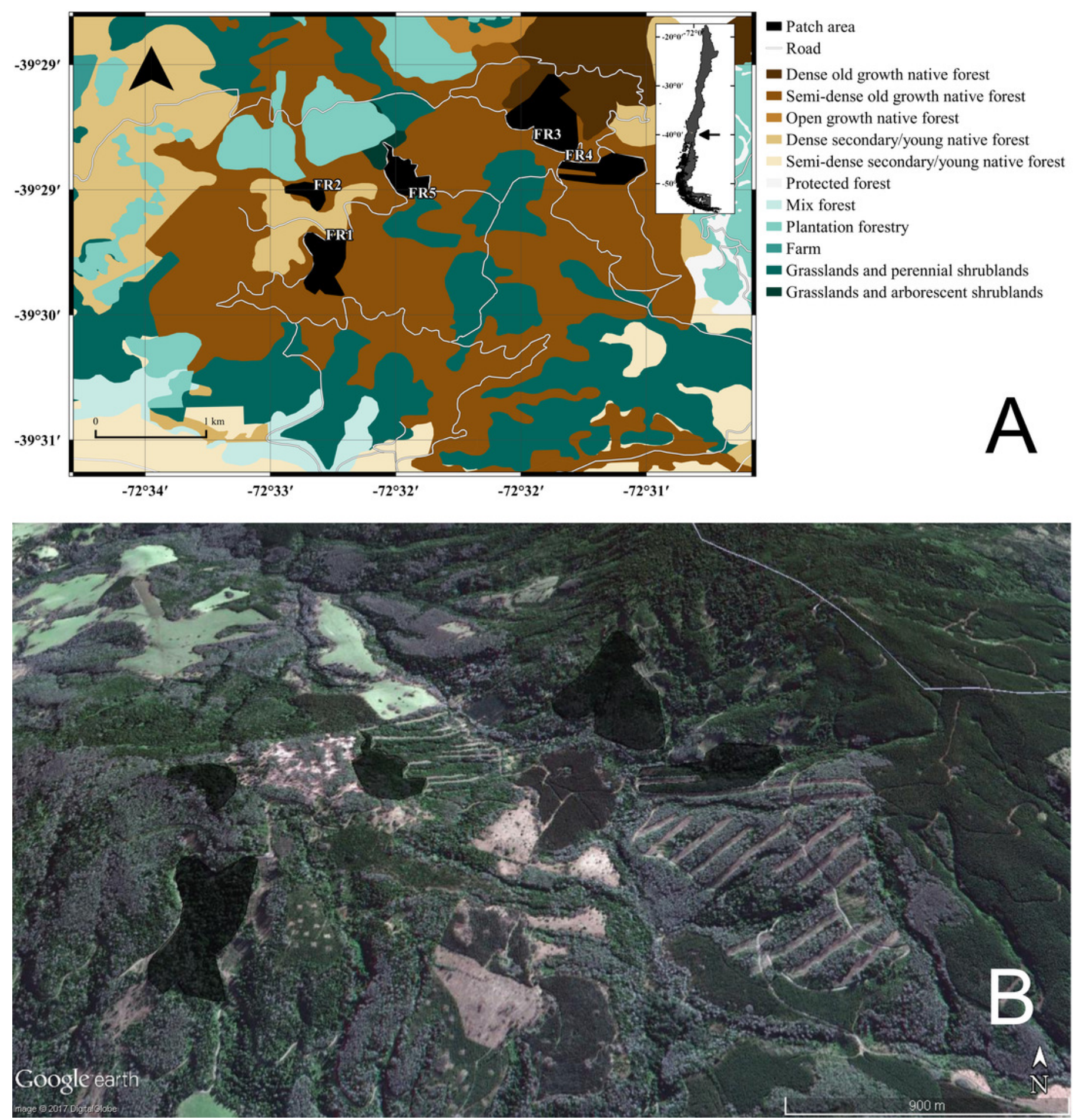


\section{Figure 2}

Spatial population structure

GENELAND analyses with posterior probability isoclines denoting the extent of genetic landscapes. Black dots represent patches analyzed. White indicates regions with the greatest posterior probability of inclusion, whereas diminishing probabilities of inclusion are proportional to the degree of coloring. a) Map of posterior probability to belong to cluster 1 , b) map of posterior probability to belong to cluster 2 .

A) Map of posterior probability to belong to cluster 1

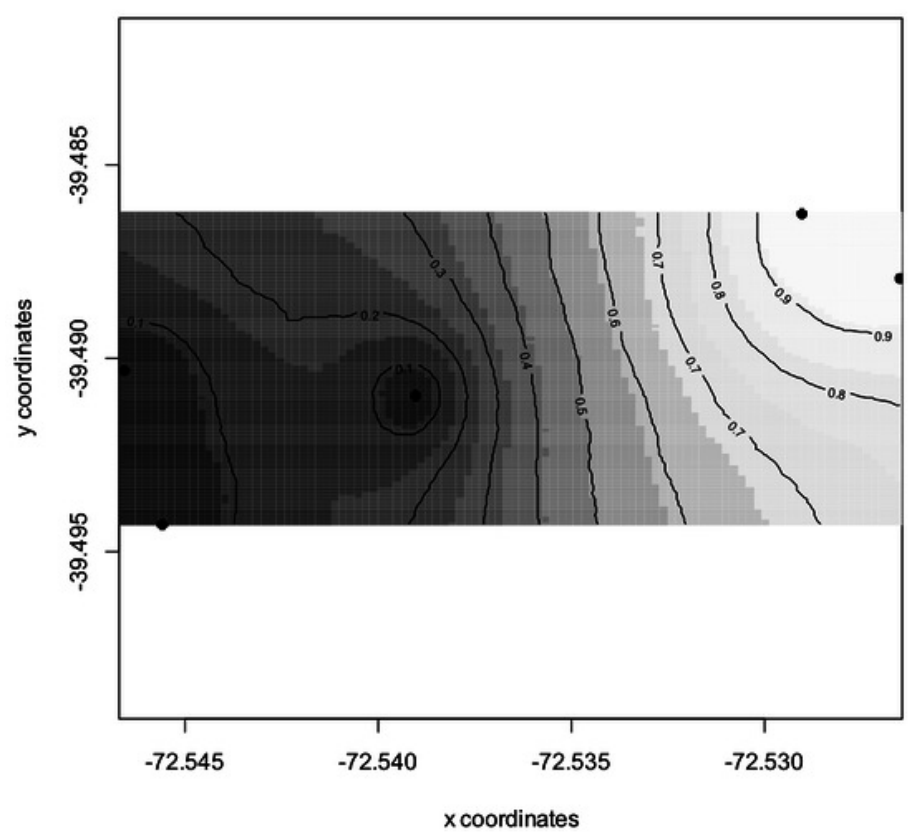

B) Map of posterior probability to belong to cluster 2

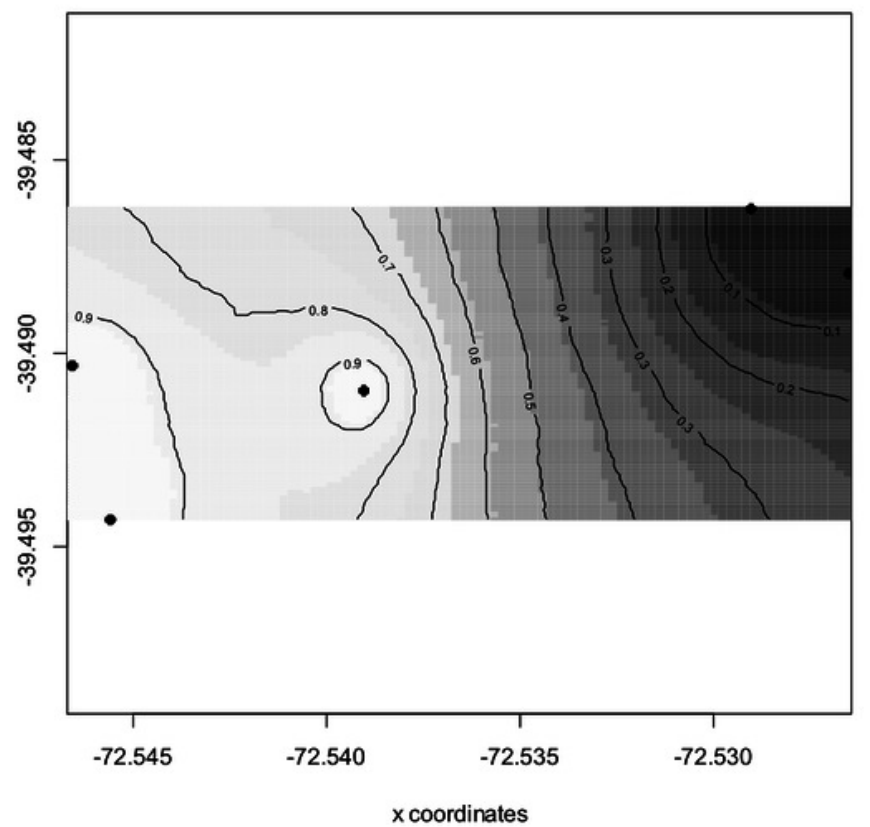


Figure 3

Effect of fragmentation and landscape matrix on the genetic structure of $O$. longicaudatus

Graphics of Pearson correlation coefficient (r). A) Isolation by Distance (IBD), B) The Leastcost Path (LCP), and C) Isolation by Resistance (IBR). $r$ value corresponds to Pearson correlation coefficient and $p$ values correspond to significance $(p \leq 0.05)$.

A) Isolation by Distance

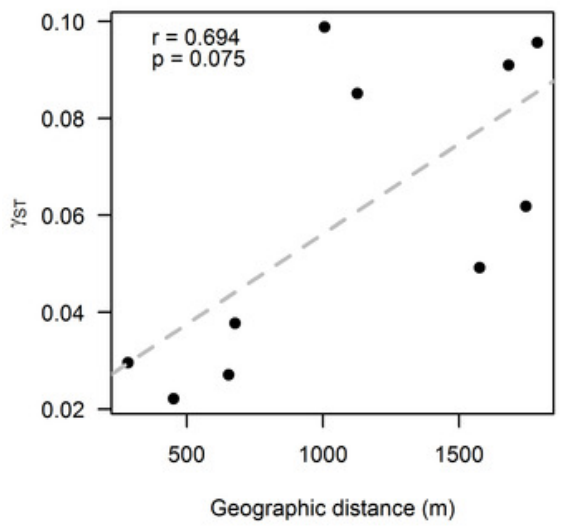

B)

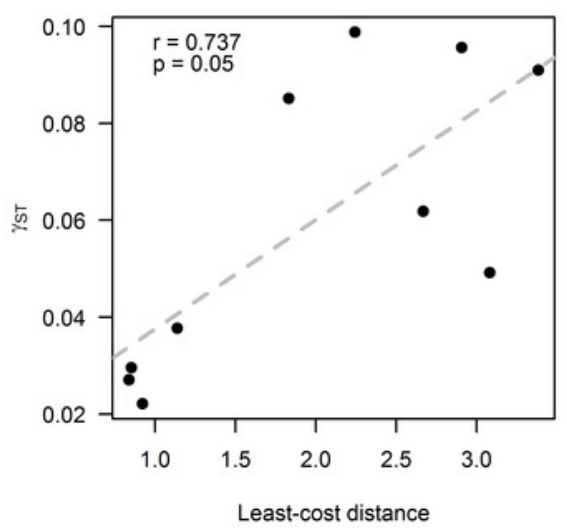

C) Isolation by Resistance

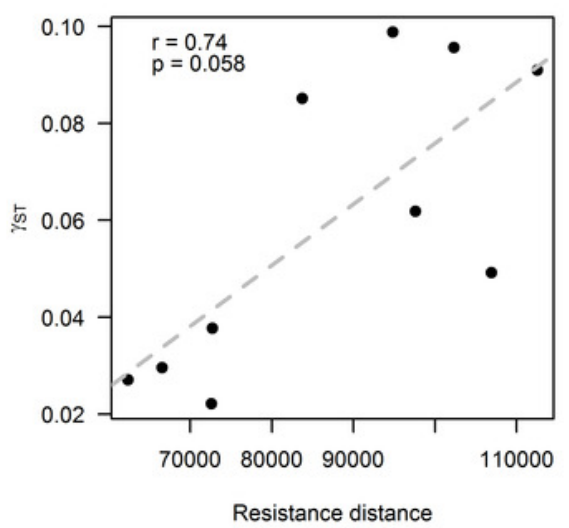




\section{Figure 4}

Results of Least Cost Paths analyses

Satellite image of the study site depicting the fragments surveyed and the least cost paths inferred for Oligoryzomys longicaudatus in the highly fragmented Valdivian Rainforest of southern Chile.

*Note: Auto Gamma Correction was used for the image. This only affects the reviewing manuscript. See original source image if needed for review.

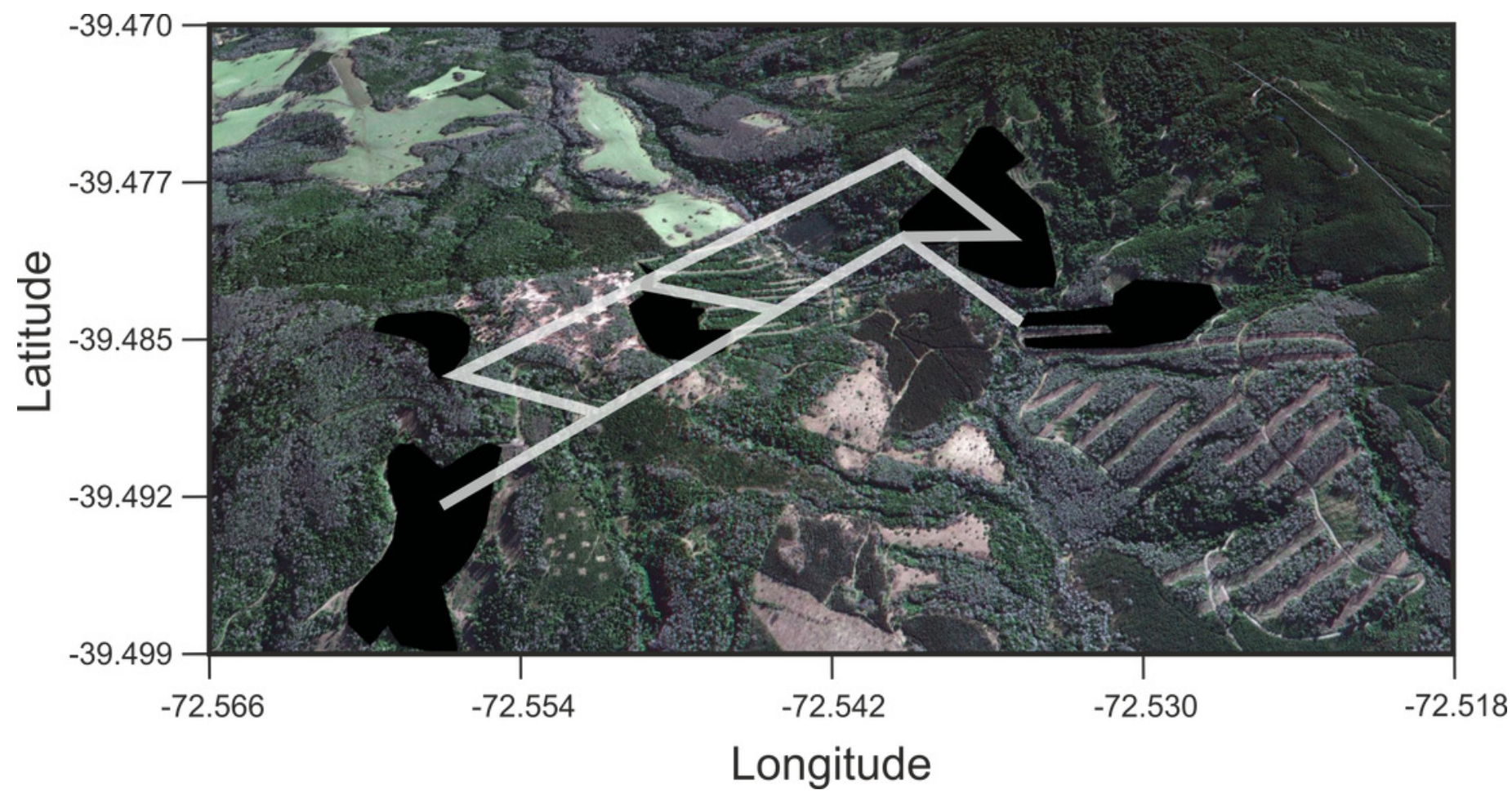

